\title{
ALARA in rhTSH-stimulated post-surgical thyroid remnant ablation: what is the lowest reasonably achievable activity?
}

\author{
Daniele Barbaro - Frederik A. Verburg • \\ Markus Luster • Christoph Reiners • Domenico Rubello
}

Received: 20 January 2010 / Accepted: 24 January 2010 /Published online: 20 March 2010

(C) Springer-Verlag 2010

For several years now recombinant human TSH (rhTSH) has been approved by the European Medicines Agency (EMEA) for the preparation of differentiated thyroid carcinoma (DTC) patients for radioiodine $\left({ }^{131} \mathrm{I}\right)$ ablation of thyroid remnants after surgery. Its effectiveness in patient preparation before ${ }^{131} \mathrm{I}$ ablation has been shown in multiple prospective studies [1-7].

In this editorial we will review the existing literature on the topic of rhTSH-stimulated ${ }^{131} \mathrm{I}$ ablation with emphasis on factors that may influence the success rate of ablation, such as the administered activity, the size of the postsurgical thyroid remnant and the amount of stable iodine present in patients at the time of ablation.

The available studies in the literature differ greatly in the activities of ${ }^{131}$ I used for ablation as well as the stages of patients eligible for inclusion, although most studies have used fairly uniform criteria for successful ablation. The

D. Barbaro

Endocrinology Unit, General Hospital of Livorno,

Livorno, Italy

F. A. Verburg $\cdot$ C. Reiners

Department of Nuclear Medicine, University of Würzburg,

Würzburg, Germany

M. Luster

Department of Nuclear Medicine, University of Ulm,

Ulm, Germany

D. Rubello $(\square)$

Department of Nuclear Medicine, PET Centre, Radiology,

Medical Physics, 'Santa Maria della Misericordia' Hospital,

Viale Tre Martiri 140,

45100 Rovigo, Italy

e-mail: domenico.rubello@libero.it available studies with their key criteria and results are summarized in Table 1. In this table, it can be seen that in those studies using $1.85 \mathrm{GBq}(50 \mathrm{mCi}){ }^{131} \mathrm{I}$ or more, there is little or no reason to doubt the equivalence of rhTSH to levothyroxine $\left(\mathrm{LT}_{4}\right)$ withdrawal for the preparation of ablation, while rhTSH stimulation significantly decreases the whole-body radiation exposure [8]. The effectiveness of ${ }^{131}$ I ablation using rhTSH, which led to its approval by European and US authorities for this indication, is corroborated by a recent retrospective study of 394 patients in which the short-term clinical recurrence did not differ between subjects prepared by $\mathrm{rhTSH}$ or $\mathrm{LT}_{4}$ withdrawal [9].

For the studies using $1.11 \mathrm{GBq}(30 \mathrm{mCi}){ }^{131} \mathrm{I}$, the results are more differentiated: whereas the studies by Barbaro et al. $[6,7]$ did not show a significant difference in the rates of successful ablation between patients prepared with rhTSH and $\mathrm{LT}_{4}$ withdrawal, Pacini et al. [5] did find a considerable difference. Some speculation is possible about the reason for the difference found by Pacini et al.; the most likely explanation is that the administration of the ablative ${ }^{131} \mathrm{I}$ activity on the second day after the last administration of rhTSH is too late. Based on a large international trial [10] it was recommended in the registration that ${ }^{131} \mathrm{I}$ should be administered on the first day after the last rhTSH injection.

The exact activity that needs to be administered in order to achieve successful ablation is still a subject of debate [11]. There are only a few studies comparing the success rate of ablation during classic $\mathrm{LT}_{4}$ withdrawal and none that compare different activities under rhTSH stimulation. Those studies which are available, such as the one by Bal et al. [12], seem to indicate that there is no real increase in ablation success rates for activities exceeding $1.85 \mathrm{GBq}$ $(50 \mathrm{mCi})$, albeit under classic withdrawal conditions. 
Table 1 An overview of prospective studies on rhTSH ablation, ordered by activity used for ablation. All studies were rhTSH vs withdrawal unless otherwise noted

\begin{tabular}{|c|c|c|c|c|c|c|}
\hline Study & $\begin{array}{l}\text { No. of patients } \\
\text { (controls) }\end{array}$ & $\begin{array}{l}\text { Stages included } \\
\text { in trial }\end{array}$ & $\begin{array}{l}{ }^{131} \mathrm{I} \text { administration } \\
\text { on day after last } \\
\text { rhTSH injection }\end{array}$ & $\begin{array}{l}{ }^{131} \text { I activity used } \\
\text { for ablation }\end{array}$ & $\begin{array}{l}\text { Criteria for } \\
\text { successful ablation }\end{array}$ & $\begin{array}{l}\% \text { Successful ablation } \\
\text { in patients (controls) }\end{array}$ \\
\hline Robbins et al. [1] & $10(0)$ & I-IV & 1 & $\begin{array}{l}1.11-9.25 \mathrm{GBq} \\
\text { dosimetry based }\end{array}$ & No visible ${ }^{131}$ I uptake & $100 \%(\mathrm{NA})$ \\
\hline Pacini et al. [2] & $32(28)$ & pT1-4 N0-1 M0 & 1 & $3.7 \mathrm{GBq}$ & $\begin{array}{l}\text { No visible }{ }^{131} \text { I uptake } \\
<0.1 \% \text { thyroid uptake }\end{array}$ & $\begin{array}{l}75 \%(86 \%), p=\mathrm{NS} \\
100 \%(100 \%)\end{array}$ \\
\hline Pilli et al. [3] & $72(0)$ & pT1-4 N0-1 M0 & 1 & $\begin{array}{l}1.85 \mathrm{GBq} v \mathrm{vs} \\
3.7 \mathrm{GBq}\end{array}$ & $\begin{array}{l}\mathrm{TG}<1 \mathrm{nmol} / 1 \\
\text { No visible }{ }^{131} \mathrm{I} \text { uptake }\end{array}$ & $\begin{array}{c}1.85 \text { GBq: } 78.9 \% ; 3.7 \\
\text { GBq: } 66.6 \%, p=\mathrm{NS} \\
\text { Both groups } 88.9 \%\end{array}$ \\
\hline Chianelli et al. [4] & $21(21)$ & pT1 N0 & 1 & $2.0 \mathrm{GBq}$ & $\begin{array}{l}\mathrm{TG}<1 \mathrm{nmol} / 1 \\
\text { No visible }{ }^{131} \mathrm{I} \text { uptake }\end{array}$ & $\begin{array}{l}85 \%(90 \%), p=\mathrm{NS} \\
90.5 \%(95.2 \%), p=\mathrm{NS}\end{array}$ \\
\hline Pacini et al. [5] & $42(30)$ & pT1-4 N0-1 M0 & 2 & $1.11 \mathrm{GBq}$ & No visible ${ }^{131}$ I uptake & $54 \%(84 \%), p<0.01$ \\
\hline Barbaro et al. [6] & $16(19)$ & I-II & $\begin{array}{r}1 ; \mathrm{LT}_{4} \text { was stopped } \\
4 \text { days before }{ }^{131} \mathrm{I}\end{array}$ & $1.11 \mathrm{GBq}$ & $\begin{array}{l}\mathrm{TG}<1 \mathrm{nmol} / 1 \\
\text { No visible }{ }^{131} \mathrm{I} \text { uptake }\end{array}$ & $\begin{array}{l}87.6 \%(79.1 \%), p=\mathrm{NS} \\
88.7 \%(75.0 \%), p=\mathrm{NS}\end{array}$ \\
\hline Barbaro et al. [7] & $52(41)$ & I-II & $\begin{array}{l}\text { 1; } \mathrm{LT}_{4} \text { was stopped } \\
4 \text { days before }{ }^{131} \mathrm{I}\end{array}$ & $1.11 \mathrm{GBq}$ & $\begin{array}{l}\mathrm{TG}<1 \mathrm{nmol} / 1 \\
\text { No visible }{ }^{131} \mathrm{I} \text { uptake }\end{array}$ & $\begin{array}{l}86.5 \%(78.0 \%), p=\mathrm{NS} \\
76.9 \%(75.6 \%), p=\mathrm{NS}\end{array}$ \\
\hline
\end{tabular}

$T G$ thyroglobulin

However, in the UK and in France two major trials are currently ongoing, both of which contain an rhTSH arm, which aim to determine what activity is required for a successful ${ }^{131}$ I ablation; the first results of these trials are expected to emerge later in the year 2010. Even if these trials may not be able to provide the definitive and nuanced answer to the question on how high the ablative ${ }^{131}$ I activity should be precisely, they will certainly be able to give a good sense of the range for further detailed research.

The second major consideration in ${ }^{131} \mathrm{I}$ ablation is the size of the thyroid remnants. This parameter strictly depends on the true extent of the total thyroidectomy, which in turn largely depends on the skill and experience of the surgeon performing the procedure, as well as the concomitant thyroid pathology such as goitre.

Measuring the size of the thyroid remnant remains a difficult matter, certainly in the immediate post-operative period where tissue oedema prevents the acquisition of a clear image and accurate measurements. A post-surgery ultrasound probably represents the easier diagnostic tool to evaluate the size of the post-operative thyroid remnants and should be part of any post-surgical evaluation. Ideally (though in clinical practice this is often difficult as ablation is often scheduled ca. 4 weeks after surgery) it should not be performed before 40-60 days after surgery to allow the post-surgical oedema to recede. Nonetheless volume estimation of small thyroid remnants remains difficult and imprecise, which in turn makes an meaningful thyroid remnant dosimetry all but impossible.
A final important point that deserves attention when trying to use lower activities of ${ }^{131} \mathrm{I}$ is the potential role of the iodine metabolism. Some important differences exist in this regard between $\mathrm{LT}_{4}$ withdrawal and rhTSH stimulation. The iodine clearance in euthyroid state is considerably higher than in hypothyroidism [8, 13-16] for example. Therefore the biological whole-body half-life of ${ }^{131} \mathrm{I}$ is shorter under rhTSH stimulation than it is under withdrawal. In contrast it is also known that the intrathyroidal ${ }^{131} \mathrm{I}$ half-life is longer during rhTSH stimulation than during $\mathrm{LT}_{4}$ withdrawal $[8,16,17]$. This can be explained by the relatively short duration of the rhTSH stimulus, which only results in a modest secretion of thyroid hormone-bound radioiodine. The ${ }^{131} \mathrm{I}$ residence time between $\mathrm{rhTSH}$ stimulation and $\mathrm{LT}_{4}$ withdrawal in normal cells does not differ however, as the thyrocytes' ${ }^{131}$ I uptake tends to be lower after rhTSH stimulation than during $\mathrm{LT}_{4}$ withdrawal $[8,16]$.

Physiology teaches us that ${ }^{131} \mathrm{I}$ uptake is, at least in part, inversely related to iodine intake and the whole-body iodine pool, as stable iodine in a pharmacological sense works as a competitive ${ }^{131} \mathrm{I}$ inhibitor. For this reason low-iodine diets have been employed for many years in preparing patients for ${ }^{131}$ I ablation [18-21]. Considering that, as stated before, iodine uptake tends to be lower under rhTSH than under withdrawal, it seems that in the case of rhTSH-stimulated ablation the need for reducing the whole-body stable iodine pool is even more important in order to maximize the therapeutic effect of the longer iodine retention under rhTSH. This may be especially true in areas with a high 
nutritional iodine intake. Consequently it is conceivable that the lower the ablative ${ }^{131} \mathrm{I}$ activity used, the more important the reduction of stable iodine becomes. The studies by Barbaro et al. [6, 7], who performed ablation under rhTSH stimulation with an activity of only $1.1 \mathrm{GBq}$ after patient preparation with a stringent diet as well as a socalled mini-withdrawal (i.e. the discontinuation of $\mathrm{LT}_{4}$ for 4 days before ${ }^{131}$ I administration as it is a source of stable iodine), seem to prove that it is possible to effectively ablate patients using only $1.11 \mathrm{GBq}$ when paying attention to the reduction of the whole-body iodine pool; the ablation success rates in the studies by Barbaro et al. were comparable with those in studies which used a higher ablative ${ }^{131}$ I activity. Furthermore, in a recently published study by Barbaro et al. [22] comparing stage-adjusted activities for rhTSH-stimulated ablation as well as several preparation regimes, it was shown that the whole-body pool of stable iodine, as measured by its urinary excretion, could be further reduced significantly by adding furosemide treatment to the preparation regime. In this study, patients pre-treated with furosemide showed a non-significant trend towards a higher success rate.

With only sparse literature to go by, it seems that the role of the reduction of the whole-body stable iodine pool before ablation certainly deserves further study - especially where it comes to measures such as the addition of a miniwithdrawal or furosemide therapy to the patient preparation procedure.

In conclusion, there are still (too) many open questions to definitively answer what activity is the lowest reasonably achievable activity for rhTSH-stimulated ${ }^{131}$ I ablation. There are however indications in the literature that lower activities of $1.85 \mathrm{GBq}$ or, at least with special preparations such as an $\mathrm{LT}_{4}$ mini-withdrawal and/or furosemide treatment, even $1.1 \mathrm{GBq}$ are attainable. Whether $1.1 \mathrm{GBq}^{131} \mathrm{I}$ is also sufficient without such extensive patient preparation, or in patients with large thyroid remnants, remains subject to further study.

\section{References}

1. Robbins RJ, Tuttle RM, Sonenberg M, Shaha A, Sharaf R, Robbins $\mathrm{H}$, et al. Radioiodine ablation of thyroid remnants after preparation with recombinant human thyrotropin. Thyroid 2001;11:865-9.

2. Pacini F, Ladenson PW, Schlumberger M, Driedger A, Luster M, Kloos RT, et al. Radioiodine ablation of thyroid remnants after preparation with recombinant human thyrotropin in differentiated thyroid carcinoma: results of an international, randomized, controlled study. J Clin Endocrinol Metab 2006;91:926-32.

3. Pilli T, Brianzoni E, Capocetti F, Castagna MG, Fattori S, Poggiu A, et al. A comparison of $1850(50 \mathrm{mCi})$ and $3700(100 \mathrm{mCi})$ 131-iodine administered doses for recombinant thyrotropin- stimulated postoperative thyroid remnant ablation in differentiated thyroid cancer. J Clin Endocrinol Metab 2007;92:3542-6.

4. Chianelli M, Todino V, Graziano FM, Panunzi C, Pace D, Guglielmi R, et al. Low-activity $(2.0 \mathrm{GBq} ; 54 \mathrm{mCi})$ radioiodine post-surgical remnant ablation in thyroid cancer: comparison between hormone withdrawal and use of rhTSH in low-risk patients. Eur J Endocrinol 2009;160:431-6.

5. Pacini F, Molinaro E, Castagna MG, Lippi F, Ceccarelli C, Agate $\mathrm{L}$, et al. Ablation of thyroid residues with $30 \mathrm{mCi}$ (131)I: a comparison in thyroid cancer patients prepared with recombinant human TSH or thyroid hormone withdrawal. J Clin Endocrinol Metab 2002;87:4063-8.

6. Barbaro D, Boni G, Meucci G, Simi U, Lapi P, Orsini P, et al. Radioiodine treatment with $30 \mathrm{mCi}$ after recombinant human thyrotropin stimulation in thyroid cancer: effectiveness for postsurgical remnants ablation and possible role of iodine content in L-thyroxine in the outcome of ablation. J Clin Endocrinol Metab 2003;88:4110-5.

7. Barbaro D, Boni G, Meucci G, Simi U, Lapi P, Orsini P, et al. Recombinant human thyroid-stimulating hormone is effective for radioiodine ablation of post-surgical thyroid remnants. Nucl Med Commun 2006;27:627-32.

8. Hänscheid H, Lassmann M, Luster M, Thomas SR, Pacini F, Ceccarelli $\mathrm{C}$, et al. Iodine biokinetics and dosimetry in radioiodine therapy of thyroid cancer: procedures and results of a prospective international controlled study of ablation after rhTSH or hormone withdrawal. J Nucl Med 2006;47:648-54.

9. Tuttle RM, Brokhin M, Omry G, Martorella AJ, Larson SM, Grewal RK, et al. Recombinant human TSH-assisted radioactive iodine remnant ablation achieves short-term clinical recurrence rates similar to those of traditional thyroid hormone withdrawal. J Nucl Med 2008;49:764-70.

10. Haugen BR, Pacini F, Reiners C, Schlumberger M, Ladenson PW, Sherman SI, et al. A comparison of recombinant human thyrotropin and thyroid hormone withdrawal for the detection of thyroid remnant or cancer. J Clin Endocrinol Metab 1999;84:387785.

11. Luster M, Clarke SE, Dietlein M, Lassmann M, Lind P, Oyen WJ, et al. Guidelines for radioiodine therapy of differentiated thyroid cancer. Eur J Nucl Med Mol Imaging 2008;35:1941-59.

12. Bal CS, Kumar A, Pant GS. Radioiodine dose for remnant ablation in differentiated thyroid carcinoma: a randomized clinical trial in 509 patients. J Clin Endocrinol Metab 2004;89:166673.

13. Löffler M, Weckesser M, Franzius C, Kies P, Schober O. Iodine excretion during stimulation with rhTSH in differentiated thyroid carcinoma. Nuklearmedizin 2003;42:240-3.

14. Menzel C, Kranert WT, Döbert N, Diehl M, Fietz T, Hamscho N, et al. rhTSH stimulation before radioiodine therapy in thyroid cancer reduces the effective half-life of (131)I. J Nucl Med 2003;44:1065-8.

15. Luster M, Sherman SI, Skarulis MC, Reynolds JR, Lassmann $\mathrm{M}$, Hänscheid $\mathrm{H}$, et al. Comparison of radioiodine biokinetics following the administration of recombinant human thyroid stimulating hormone and after thyroid hormone withdrawal in thyroid carcinoma. Eur J Nucl Med Mol Imaging 2003;30: 1371-7.

16. Remy H, Borget I, Leboulleux S, Guilabert N, Lavielle F, Garsi J, et al. 131I effective half-life and dosimetry in thyroid cancer patients. J Nucl Med. 2008;49:1445-50.

17. Dobert N, Menzel C, Oeschger S, Grunwald F. Differentiated thyroid carcinoma: the new UICC 6th edition TNM classification system in a retrospective analysis of 169 patients. Thyroid. 2004; 14:65-70.

18. Goslings BM. Proceedings: effect of a low iodine diet on 131-I therapy in follicular thyroid carcinomata. J Endocrinol. 1975;64:30. 
19. Maxon HR, Thomas SR, Boehringer A, Drilling J, Sperling MI, Sparks JC, et al. Low iodine diet in I-131 ablation of thyroid remnants. Clin Nucl Med. 1983;8:123-6.

20. Pluijmen MJ, Eustatia-Rutten C, Goslings BM, Stokkel MP, Arias AM, Diamant M, et al. Effects of low-iodide diet on postsurgical radioiodide ablation therapy in patients with differentiated thyroid carcinoma. Clin Endocrinol (Oxf). 2003;58:42835 .
21. Park JT, Hennessey JV. Two-week low iodine diet is necessary for adequate outpatient preparation for radioiodine rhTSH scanning in patients taking levothyroxine. Thyroid. 2004;14:57-63.

22. Barbaro D, Grosso M, Boni G, Volterrani D, Lapi P, Pasquini C, et al. Recombinant human TSH and ablation of post-surgical thyroid remnants in differentiated thyroid cancer: the effect of pretreatment with furosemide and furosemide plus lithium. Eur J Nucl Med Mol Imaging 2009; doi 10.1007/-s00259-009-1254-2. 